\title{
TH1 cytokine response to HCV peptides in Egyptian health care workers: a pilot study
}

\author{
Mona M Rafik*, Alaa El-Dien MS Hosny², Khaled O Abdallah', Amal A Abbas', Rania A Abo Shady', \\ Dina A Soliman ${ }^{1}$, Khaled M Nasr El-Din Rakha ${ }^{2}$ and Shahira F Alfedawy ${ }^{1}$
}

\begin{abstract}
Our objective was to elucidate the effects of different HCV peptides on TH1 cytokine synthesis (interleukin 2(IL2), gamma interferon (INFY) and tumor necrosis factor a (TNF a)), in a proliferative response in a high risk population of HCV seronegative aviremic Egyptian healthcare workers (HCW). We studied the $\mathrm{TH} 1$ cytokine response to different HCV peptides among $47 \mathrm{HCW}$ with and without evidence of HCV infection. Participants were classified according to the proliferation index (PI) in a CFSE proliferation assay as an indicator of previous exposure to HCV. Cytokines were analyzed using Luminex XMAP technology. Results showed that positive PI HCW produced a higher IL2 in response to all HCV peptides except NS4, a higher IFNy response to NS3 and NS4 and no difference in TNFa response when compared to the negative PI HCWs. When compared to chronic HCV HCW, positive PI HCW showed no difference in the IL2 response, a higher IFNy response to NS4 and NS5 HCV peptides and a higher TNFa response to all peptides. In conclusion the magnitude and type of cytokines produced in HCV infection is critical in determining the outcome of infection. NS4 \& NS5 HCV peptides induce a protective TH1 response in positive PI HCW
\end{abstract}

Keywords: CFSE, Proliferation assay

\section{Background}

Prospective studies of healthcare workers (HCW) after occupational exposure have identified the average hepatitis $\mathrm{C}$ virus $(\mathrm{HCV})$ transmission rate associated with contaminated needle sticks to be $1.8 \%$ [1]. Kubitschke et al. 2007 carried out a systematic review of 22 studies reporting a total of 6956 injuries involving HCVcontaminated needles and demonstrated seroconversion rates ranging between $0 \%$ and $10.3 \%$, with a mean of $0.75 \%$ with worldwide differences in HCV seroconversion rates. This suggests that genetic factors might provide some level of natural resistance against HCV [2]. Little is known about the prevalence of HCV among $\mathrm{HCW}$ in Egypt, where the highest worldwide prevalence of $\mathrm{HCV}$ exists. In recent studies the prevalence of $\mathrm{HCV}$ antibody in Egyptian HCW workers was found to range from $11.2 \%$ to $16.6 \%[3,4]$ and HCV viraemia was found to be $8 \%$, but the prevalence was not significantly different than that found among non-medical personnel.

\footnotetext{
* Correspondence: monarafik@hotmail.com

${ }^{1}$ Ain Shams Faculty of Medicine Clinical Pathology Department, Abbassia square, Cairo, Egypt

Full list of author information is available at the end of the article
}

Previous studies in Egypt concluded that the infections were more likely to be community-acquired and not occupationally related but Rafik et. al [3] added that workers in the dialysis unit and laboratory technicians showed significantly higher prevalence than other job groups in the same departments.

$\mathrm{HCV}$-specific T-cell responses have been described in studies of exposed HCV-seronegative individuals [2-5] where these responses were found to be broad and associated with risk factors for $\mathrm{HCV}$ exposure, suggesting that they reflected true exposure to $\mathrm{HCV}$ in seronegative persons. Evidence for the presence of a cellular immune response was detected by a CFSE assay where a positive proliferative response to different $\mathrm{HCV}$ peptides was detected in 27/60 aviraemic seronegative Egyptian laboratory and blood bank HCW [6].

Conflicting results have been reported about the magnitude, breadth, quality and duration of HCV specific immune responses in different clinical settings of $\mathrm{HCV}$ infection. Due to the difficulty in identifying persons who successfully clear acute HCV; examination of immune responses in large numbers of exposed but uninfected persons provides an alternate strategy for 
identification of protective immune responses in $\mathrm{HCV}$. Our aim was thus to research one aspect of the protective $\mathrm{HCV}$ immune response in $\mathrm{HCW}$, the TH1cytokine response to different $\mathrm{HCV}$ peptides in a high risk population of Egyptian $\mathrm{HCW}$, to elucidate the effects of different HCV peptides on cytokine synthesis in a proliferative response. The hypothesis was that the type and level of TH1 cytokines produced during their HCV exposure may be a critical determinant of viral clearance

\section{Material and methods}

The study began with screening 240 of the staff working in Ain shams University Hospitals (Internal Medicine Hospital). The study sample was composed of different categories of professionals. One hundred eighty seven health care workers (personnel who either had direct contact with patients or with potentially infectious clinical specimens as blood and body fluids.) were enrolled in the study and included 48 resident doctors, 77 nurses, 17 technicians and 45 workers. A control group was included; consisting of 53 of the administrative employees (secretaries, personnel management employees, accounting employees, etc...) in the same hospital who had no contact with patients, or with material used by them.

After written consent a detailed questionnaire was obtained from each participant with special emphasis on occupational risk factors for HCV which included duration of employment, exposure to needle stick injuries, accidental splashes of blood or body fluids onto mucous membranes and failure to adhere to essential infection control procedures (gloves). All participants were initially tested for ALT level, and HCV-antibody carried out by third-generation enzyme-linked immunosorbent assay (ELISA) for serum anti-HCV antibodies. HCV RNA detection was carried out by Real-time RT-PCR for all participants:

The study showed that according to the occupation laboratory technicians had a greater prevalence of infection than other occupations $(\mathrm{p}<0.01)$ in different departments of the hospital.

Among the $187 \mathrm{HCW}$ included in the study, 67.9\% reported exposure to needle stick injuries, $56.7 \%$ reported splashes of blood or body fluids to the eye or mucous membranes, $82.4 \%$ handled body fluids as part of their job description, $17.6 \%$ did not use gloves, $53.5 \%$ used gloves and $28.9 \%$ used gloves intermittently. HCV infection was statistically significantly associated with failure to use gloves $(\mathrm{p}<0.05)$.

After determining the HCV status of the previous subjects, 60 were selected from the laboratory and blood bank personnel since they had the greater prevalence of infection than all other HCW and the highest exposure to blood (Table 1). They included $60 \mathrm{HCWs}$ (38 males and 22 females) with a mean age of $36 \pm 10$ years who
Table 1 Demographic characteristics of HCWs

\begin{tabular}{|c|c|c|}
\hline Characteristic & Number (Total = 60) & Percentage \\
\hline \multicolumn{3}{|l|}{ Gender } \\
\hline Female & 22 & $36.7 \%$ \\
\hline Male & 38 & $63.3 \%$ \\
\hline \multicolumn{3}{|l|}{ Age (years) } \\
\hline$<25$ & 5 & $8.4 \%$ \\
\hline $25-40$ & 43 & $71.7 \%$ \\
\hline$>40$ & 12 & $19.9 \%$ \\
\hline \multicolumn{3}{|l|}{$H C V R T-P C R$} \\
\hline Positive & 10 & $16.7 \%$ \\
\hline Negative & 50 & $83.3 \%$ \\
\hline \multicolumn{3}{|l|}{ Work place } \\
\hline Laboratory & 45 & $75 \%$ \\
\hline Blood Bank & 15 & $25 \%$ \\
\hline \multicolumn{3}{|l|}{ Job category } \\
\hline Worker & 15 & $25 \%$ \\
\hline Resident physician & 13 & $21.7 \%$ \\
\hline Nurse & 7 & $11.7 \%$ \\
\hline Technician & 25 & $41.7 \%$ \\
\hline \multicolumn{3}{|l|}{ Prick injury } \\
\hline Positive history & 31 & $51.7 \%$ \\
\hline Negative history & 29 & $48.3 \%$ \\
\hline \multicolumn{3}{|l|}{ Family history } \\
\hline Positive history & 14 & $23.3 \%$ \\
\hline Negative history & 46 & $76.7 \%$ \\
\hline
\end{tabular}

worked at Ain Shams University laboratory and blood bank. Only 10 of them were found to be viraemic (HCV $\mathrm{PCR}+\mathrm{ve}$ ) and were $\mathrm{HCV}$ antibody + ve while all the other were seronegative for $\mathrm{HCV}$ antibody and aviraemic for $\mathrm{HCV}$.

PBMCs from study subjects were isolated immediately from fresh heparinized blood by Ficoll-Hypaque density gradient centrifugation using standard techniques and immediately tested for antigen-specific cell proliferation and CFSE assays [7]. Proliferation assays were performed without or after 5, 6-carboxyfluorescein diacetate succinimidyl ester.

Freshly isolated cells were resuspended in PBS that had been supplemented with 5\% FCS (Eurobio), to a final cell concentration of 1 million / ml. CFSE was added at a concentration of $5 \mu \mathrm{M} / \mu \mathrm{L}$ (Molecular probes, Invitrogen). After $10 \mathrm{~min}$ incubation, at $37^{\circ} \mathrm{C}$, in the dark cells were pelleted, washed extensively, and resuspended in $1 \mathrm{ml}$ of ice cold RPMI-1640 that had been supplemented with 10\% FCS, 1\% HEPES, $0.2 \%$ Gentamicin. CFSE labeled cells were then stimulated in a 7-day culture with (PHA) (Sigma Aldrich) $(10 \mu \mathrm{g} / \mathrm{ml})$ as a positive control and HCV peptides (core (aa 2-120), nonstructural protein 3 (NS3) (1192-1457), nonstructural 
protein 4 (NS4) (aa 1569-1931), and nonstructural protein 5 (NS5) (aa 2054-2995core,) (Chiron) (4 $\mu$ g /well) for 7 days in $10 \% \mathrm{CO} 2$ at $37^{\circ} \mathrm{C}$. Unstimulated cells with medium only were used as negative controls.

On the seventh day GUAVA EASY cyte 4 color flow cytometry was used to determine the percent of the parent cells and the mean fluorescence intensity (MFI) of the CFSE stained cells. The Proliferation index (P.I) was calculated according to Lyons and Parish, 1994 [7]. P.I was considered + ve if it was higher than the cut off values calculated (= Mean P.I of positive Control group x1 .68 standard deviation (SD) for each peptides used).

Cell culture supernatants from the peripheral blood mononuclear cells (PBMCs) stimulated by HCV peptides in the CFSE proliferation assay for $47 \mathrm{HCW}$ were collected and stored at $-80^{\circ} \mathrm{C}$ until assayed. The personnel included in this study were divided into two groups:

\section{1) HCV double negative (HCWs)}

(negative PCR \& antibody) (Group I): This group included $37 \mathrm{HCW}$ sho had normal serum alanine aminotransferase, serum aspartate aminotransferase, and negative $\mathrm{HCV}$ antibody \& were negative for $\mathrm{HCV}$ RNA. According to the proliferation index (PI) in the CFSE proliferation assay for the HCV peptides, group $1 \mathrm{HCW}$ was further classified into 2 subgroups.

Group1a) Positive proliferation index (+ve P.I) HCWs: Subjects whose cells showed a P. I more than the cut off values of the PI for the HCV specific peptides of the chronic group in the CFSE assay (group 2) (27 samples were available).

Group1b) Negative proliferation index (-ve P.I) HCWs: Subjects in group I whose cells showed a P.I less than the cut off values of the PI of HCVspecific peptides of the chronic group in the CFSE assay (10 samples).

2) Chronic HCV HCWs (positive Control group): (Double Positive: PCR \& antibody for HCV) (Group II)) which consisted of $10 \mathrm{HCW}$ $\mathrm{HCV}$ proteins used were derived from the HCVgenotype 1 sequence and encoded core (aa 2-120), nonstructural protein 3 (NS3) (1192-1457), nonstructural protein 4 (NS4) (aa 1569-1931), and nonstructural protein 5 (NS5) (aa 2054-2995).

\section{TH1 Cytokine analysis}

All cell culture supernatants were analyzed using Luminex xMAP technology for IL2, IFN $\gamma$ and TNF $\alpha$. Reagents were supplied by RED diagnostics designed for use with the Luminex100 ${ }^{\mathrm{Ts}}$, Analyzer manufactured by Luminex Corporation. (R\&D systems, Minneapolis, United States of America).
All protocols for this study were reviewed and approved by the Ain Shams Faculty of Medicine ethics committee and all participants provided written informed consent.

\section{Statistical analysis}

IBM statistical package for social sciences (SPSS statistics) (V. 19.0, IBM Corp., USA, 2010) was used for data analysis. Data was expressed as median and percentiles for quantitative non-parametric measures utilizing Wilcoxon Rank Sum test, Ranked Spearman correlation test and Kruskall Wallis test

\section{Results}

Cytokine responses to HCV peptides produce a similar pattern within each individual group

All of the HCV peptides, structural and nonstructural, (Core, NS3, NS4 and NS5) studied produced a similar IL2 and INF $\gamma$ response with no significant difference between them in each group. However in the positive PI HCW the TNF $\alpha$ response was significantly higher than the other studied groups (Table 2). Correlations between the cytokines studied in response to the different $\mathrm{HCV}$ peptides within each group were done and Spearman correlation coefficient $\left(R_{s}\right)$ is reported (Table 3$)$.

In positive PI HCW both structural (core) and nonstructural (NS3 and NS5) HCV peptides produced a positive correlation between IL2 and INF $\gamma$ while in the negative HCW only nonstructural peptides (NS4 \& NS5) did. There was no correlation between IL2 and TNF produced in response to $\mathrm{HCV}$ peptides in all studied groups. There was a positive correlation between INFy and TNF $\alpha$ produced in response to core NS4 and NS5 in positive PI HCW and to NS3 in chronic HCV HCW.

Table 2 Cytokine response to different HCV peptides in studied groups (Kruskall Wallis)

\begin{tabular}{ccccccc}
\hline \multirow{2}{*}{ Group } & Cytokine & \multicolumn{3}{c}{ Median cytokine (pg/ml) } & p \\
\cline { 3 - 6 } & & \multicolumn{4}{c}{ HCV PEPTIDES } \\
\cline { 3 - 6 } & & CORE & NS3 & NS4 & NS5 \\
\hline Positive PI HCW & IL2 & 16.855 & 36.18 & 17.405 & 20.18 & 0.209 \\
& IFN- $\gamma$ & 2.16 & 11.4 & 3.31 & 2.0 & 0.662 \\
& TNFa & 60.2 & 66.4 & 75.8 & 117 & $\mathbf{0 . 0 1 2}$ \\
Negative PI HCW & IL2 & 1.6 & 6.8 & 3.7 & 3.33 & 0.196 \\
& IFN- $\gamma$ & .83 & 1.36 & 0 & 0.83 & 0.588 \\
& TNFa & 14.8 & 157.4 & 30.4 & 79.5 & 0.168 \\
Chronic HCV HCW & IL2 & 10.9 & 16.1 & 8.7 & 28.33 & 0.807 \\
& IFN- $\gamma$ & .065 & 0.35 & 0.28 & 0.175 & 0.583 \\
& TNFa & 16.2 & 18.0 & 25.8 & 20.3 & 0.989 \\
\hline$p^{*} \leq 0.05$ significant. & & & & & &
\end{tabular}

$p^{*} \leq 0.05$ significant. 
Table 3 Correlation between cytokine responses to HCV Peptides within individual groups

\begin{tabular}{|c|c|c|c|c|c|c|c|c|c|}
\hline \multirow[t]{2}{*}{ Group } & \multicolumn{3}{|c|}{ INFY \& IL2 } & \multicolumn{3}{|c|}{ IL2 \& TNFa } & \multicolumn{3}{|c|}{ TNFa \& INFY } \\
\hline & HCV Peptide & Rs & $p$ & HCV Peptide & Rs & $p$ & HCV Peptide & Rs & $p$ \\
\hline \multirow[t]{4}{*}{ 1-a:Positive P.I HCWs: } & Core & 0.514 & 0.014 & Core & 0.279 & 0.21 & Core & 0.447 & 0.028 \\
\hline & NS3 & 0.51 & 0.024 & NS3 & -0.1 & 0.6 & NS3 & 0.2 & 0.3 \\
\hline & NS4 & 0.226 & 0.311 & NS4 & 0.797 & 0.44 & NS4 & 0.436 & 0.026 \\
\hline & NS5 & 0.512 & 0.015 & NS5 & 0.127 & 0.60 & NS5 & 0.445 & 0.03 \\
\hline \multirow[t]{4}{*}{ 1-b: Negative P.I HCWs: } & Core & 0.403 & 0.282 & Core & -0.53 & 0.14 & Core & -0.153 & 0.694 \\
\hline & NS3 & 0.451 & 0.223 & NS3 & -0.6 & 0.1 & NS3 & -0.5 & 0.1 \\
\hline & NS4 & 0.893 & 0.003 & NS4 & 0.47 & 0.24 & NS4 & -0.035 & 0.924 \\
\hline & NS5 & 0.72 & 0.029 & NS5 & 0.644 & 0.06 & NS5 & 0.338 & 0.339 \\
\hline \multirow[t]{4}{*}{ 2-Chronic HCV HCW } & Core & -0.395 & 0.439 & Core & -0.6 & 0.28 & Core & -0.112 & 0.858 \\
\hline & NS3 & -0.894 & 0.041 & NS3 & -0.1 & 0.8 & NS3 & 0.8 & 0.04 \\
\hline & NS4 & 0.051 & 0.935 & NS4 & 0.60 & 0.285 & NS4 & 0.698 & 0.123 \\
\hline & NS5 & -0.213 & 0.686 & NS5 & -0.5 & 0.391 & NS5 & 0.759 & 0.08 \\
\hline
\end{tabular}

Spearman correlation coefficient $\left(R_{s}\right)$ is reported.

Strong correlations $\left(\left|R_{s}\right| \geq 0.5\right)$ are indicated in bolded print; black indicates positive correlations; italics indicates negative correlations.

\section{Differentiating characteristics of the cytokine response} between groups

There was no difference in IL2 response to all the HCV peptides between positive $\mathrm{HCW}$ and the chronic $\mathrm{HCV}$ HCWs group (Table 4) but there was a higher IL2 response to all the HCV peptides except NS4 in comparison to the negative HCW Only the core peptide resulted in a higher IL2 response in the chronic HCV HCW compared to the negative PI HCW.

Regarding the IFN $\gamma$ response in positive $\mathrm{HCW}$ only NS4 and NS5 peptides resulted in a significantly stronger IFNy response compared to chronic $\mathrm{HCV} \mathrm{HCWs}$ and a higher response to NS3and NS4 peptides compared to the negative HCW group (Table 5).

The IFN gamma response to NS4 in positive HCW is significantly higher than in negative $\mathrm{HCW}$ whereas there was no significant difference in the IL2 response to this peptide. There was no correlation between both cytokines in response to NS4 in positive HCW and there was such a correlation in the negative HCW.

In this study NS3 peptide evoked the strongest INFy response in all groups but this was not significantly different except in the positive HCW who were higher than the negative HCW. The IL2 response to the NS3 peptide in the positive $\mathrm{HCW}$ was higher than that in the negative HCW with the presence of a positive correlation with IFN $\gamma$ which could not be detected in the negative HCW. The HCV NS3 peptide seems to stimulate a predominantly IL2 dependent INF $\gamma$ production in positive PI HCW.

The TNF $\alpha$ response to the different $\mathrm{HCV}$ peptides showed no difference between positive and negative PI $\mathrm{HCW}$ with a significantly higher response to all peptides between positive PI HCW and chronic HCV HCW. NS3 and NS5 peptides produced a lower TNF $\alpha$ in chronic HCV HCW than even the negative PI HCW (Table 6).

The NS4 and NS5 peptide results typically display a type $1 \mathrm{TH}$ cytokine profile in positive PI HCW which is not true in chronic $\mathrm{HCV} \mathrm{HCW}$ where they induce a lower INF $\gamma$ and TNF $\alpha$ response.

\section{Discussion}

Clearance of HCV-RNA may not necessarily correlate with the appearance of acquired immunity and may be

Table 4 Comparison between the IL2 responses to different HCV peptides within the studied groups

\begin{tabular}{|c|c|c|c|c|c|c|c|c|c|}
\hline \multirow{3}{*}{$\begin{array}{c}\text { HCV } \\
\text { peptide }\end{array}$} & \multicolumn{9}{|c|}{ Groups tested } \\
\hline & $\begin{array}{l}\text { Positive P.I } \\
\text { HCWs }\end{array}$ & $\begin{array}{c}\text { Chronic HCV } \\
\text { HCW }\end{array}$ & $p$ & $\begin{array}{l}\text { Positive P.I } \\
\text { HCWs }\end{array}$ & $\begin{array}{c}\text { Negative P.I } \\
\text { HCWs }\end{array}$ & $p$ & $\begin{array}{c}\text { Chronic HCV } \\
\text { HCW }\end{array}$ & $\begin{array}{c}\text { Negative P.I } \\
\text { HCWs }\end{array}$ & $p$ \\
\hline & \multicolumn{3}{|c|}{ Median IL2 (pg/ml) } & \multicolumn{3}{|c|}{ Median IL2 (pg/ml) } & \multicolumn{3}{|c|}{ Median IL2 (pg/ml) } \\
\hline CORE & 16.85 & 10.995 & 0.575 & 16.85 & 1.6 & 0.006 & 10.995 & 1.6 & 0.009 \\
\hline NS3 & 36.18 & 16.1 & 0.165 & 36.18 & 6.82 & 0.013 & 16.11 & 6.82 & 0.461 \\
\hline NS4 & 17.40 & 8.7 & 0.574 & 17.40 & 3.69 & 0.071 & 8.7 & 3.69 & 0.305 \\
\hline NS5 & 20.18 & $28 . .33$ & 0.674 & 20.18 & 3.33 & 0.046 & 28.33 & 3.33 & 0.093 \\
\hline
\end{tabular}

Significant difference (Wilson Rank Sum) $(\mathrm{p} \leq 0.5)$ is indicated in bolded black print. 
Table 5 Comparison between INFy responses to different HCV peptides within the studied groups

\begin{tabular}{|c|c|c|c|c|c|c|c|c|c|}
\hline \multirow{3}{*}{$\begin{array}{l}\text { HCV } \\
\text { peptide }\end{array}$} & \multicolumn{9}{|c|}{ Group tested } \\
\hline & $\begin{array}{c}\text { Positive P.I } \\
\text { HCWs }\end{array}$ & $\begin{array}{c}\text { Chronic HCV } \\
\text { HCW }\end{array}$ & $p$ & $\begin{array}{c}\text { Positive P.I } \\
\text { HCWs }\end{array}$ & $\begin{array}{c}\text { Negative P.I } \\
\text { HCWs }\end{array}$ & $p$ & $\begin{array}{c}\text { Chronic HCV } \\
\text { HCW }\end{array}$ & $\begin{array}{c}\text { Negative P.I } \\
\text { HCWs }\end{array}$ & $p$ \\
\hline & \multicolumn{3}{|c|}{ Median INFY $(\mathrm{pg} / \mathrm{ml})$} & \multicolumn{3}{|c|}{ Median INFY (pg/ml) } & \multicolumn{3}{|c|}{ Median INFY (pg/ml) } \\
\hline CORE & 2.16 & 0.065 & 0.103 & 2.16 & 0.83 & 0.119 & 0.065 & 0.83 & 0.376 \\
\hline NS3 & 11.4 & 0.35 & 0.055 & 11.4 & 1.36 & 0.031 & 0.35 & 1.36 & 1 \\
\hline NS4 & 3.31 & 0.28 & 0.026 & 3.31 & 0 & 0.004 & 0.28 & 0 & 0.811 \\
\hline NS5 & 2 & 0.2 & 0.041 & 2 & 1 & 0.135 & 0.2 & 1 & 0.295 \\
\hline
\end{tabular}

Significant difference (Wilson Rank Sum) $(\mathrm{p} \leq 0.5)$ is indicated in bolded black print.

an explanation for the rather low seroconversion rate after occupational exposure to HCV [8]. Studies indicate that selected high-risk subjects can mount an effective immune response against $\mathrm{HCV}$ infection in the absence of antibody production and that they may have a higher likelihood of viral clearance in that setting [9-14].

The immunodominance hierarchies within HLA-A2 -restricted HCV-specific CD8+ T cell responses were recently studied to determine if they are linked to naiveprecursor frequency [15]. Precursor frequencies to Core132, NS3 1406 and NS5B 2594 specific epitopes were conserved across the healthy donors although they varied significantly between epitopes suggesting that a clear hierarchy of naive HCV-specific CD8 $+\mathrm{T}$ cell precursor frequencies exists in healthy donors [15]. The NS3 1406 epitope had the highest naive-precursor frequency in healthy donors and the most frequently targeted epitope in chronic HCV-infected patients, both ex vivo and after in vitro stimulation, whereas the core 132 epitope was rarely targeted in most studies [16-19]. For assessing human antiviral $\mathrm{T}$ cell responses the functions quantified simultaneously include up regulation of IFN $\gamma$ and IL2 [20-22]. In this study of all the HCV peptides studied NS3 peptide (1192 to 1457) evoked the highest IL2 response in both positive and negative HCW whereas the core peptide produced the lowest IL2 response. The difference in the IL2 induced was significantly higher in positive $\mathrm{HCW}$ than the negative $\mathrm{HCW}$ for all peptides except NS4. The most predominant IL2 response in chronic $\mathrm{HCV} \mathrm{HCW}$ was obtained by NS5 and the lowest was by the NS4 peptide but the only significantly higher IL2 response compared to the negative $\mathrm{HCW}$ was that obtained by the core peptides. When compared to the positive $\mathrm{HCW}$, all the $\mathrm{HCV}$ peptides in chronic HCV HCW produced lower levels of IL2 but with no significant difference.

IL2 plays a critical role in the regulation of Th1 and Th2 responses and impacts INFY production [23]. INFY production in chronic $\mathrm{HCV} \mathrm{HCW}$ was not significantly different from the negative PI HCW for all peptides tested. At the same time positive PI HCW showed a significantly higher INFY in response to NS4 and NS5 than the chronic HCV HCW and a significantly higher INFY in response to NS3 and NS4 than the negative HCW. The failure to produce INFy, in response to HCV NS4 peptide in chronically $\mathrm{HCV}$-infected patients has been previously documented [24].

IL2 cytokine secretion in response to a panel of recombinant $\mathrm{HCV}$ antigens in patients with acute $\mathrm{HCV}$ has been studied previously and showed that patients with self-limited disease had a significant secretion of IL2 [25] and those who developed chronicity had significantly lower IL-2 [26] and INFy production than those cases who recovered $[27,28]$. The previously described 'stunned' T cell phenotype in chronic HCV infection $[20,29]$ was seen in this study for almost all of the nonstructural peptides (NS4 and NS5) with near significance for NS3 ( $\mathrm{p}=0.055)$. Resolved HCV infection is associated with $\mathrm{T}$-cells responses with higher IFNy predominantly targeting nonstructural proteins [30-34].

Table 6 Comparison between the TNFa response to different HCV peptides within the studied groups

\begin{tabular}{|c|c|c|c|c|c|c|c|c|c|}
\hline \multirow{3}{*}{$\begin{array}{l}\text { HCV } \\
\text { peptide }\end{array}$} & \multicolumn{9}{|c|}{ Groups tested } \\
\hline & $\begin{array}{c}\text { Positive P.I } \\
\text { HCWs }\end{array}$ & $\begin{array}{c}\text { Chronic HCV } \\
\text { HCW }\end{array}$ & $p$ & $\begin{array}{c}\text { Positive P.I } \\
\text { HCWs }\end{array}$ & $\begin{array}{c}\text { Negative P.I } \\
\text { HCWs }\end{array}$ & $p$ & $\begin{array}{c}\text { Chronic HCV } \\
\text { HCWs }\end{array}$ & $\begin{array}{c}\text { Negative P.I } \\
\text { HCWs }\end{array}$ & $p$ \\
\hline & \multicolumn{3}{|c|}{ Median TNFa (pg/ml) } & \multicolumn{3}{|c|}{ Median TNFa (pg/ml) } & \multicolumn{3}{|c|}{ Median TNFa (pg/ml) } \\
\hline CORE & 60.18 & 16.17 & 0.026 & 60.18 & 14.81 & 0.063 & 16.17 & 14.81 & 0.841 \\
\hline NS3 & 66.4 & 18 & 0.002 & 66.4 & 157.4 & 0.678 & 18 & 157.4 & 0.007 \\
\hline NS4 & 75.8 & 25.8 & 0.002 & 75.8 & 30.4 & 0.374 & 25.8 & 30.4 & 0.277 \\
\hline NS5 & 117 & 20.3 & 0.000 & 117 & 79.5 & 0.112 & 20.3 & 79.5 & 0.017 \\
\hline
\end{tabular}

Significant difference (Wilson Rank Sum) $(p \leq 0.5)$ is indicated in bolded black print. 
The lowest magnitude of responses in persons with resolved infection was to the relatively small core protein, and these responses were not significantly different from persons with chronic infection [35]. Perrella et al. (2009) [36] searched for evidence of hepatitis $C$ virus-specific interferon gamma-positive $\mathrm{T}$ cells in health care workers in an infectious disease department. They found that levels of HCV-specific IFN-gamma-positive cells were higher in the HCWs compared with the infected patients and healthy blood donors. The investigators concluded that a clinically silent persistent exposure to $\mathrm{HCV}$, through some as-yet undetermined mechanism, may induce a virus-specific IFN-gamma-producing CD8 (+) Tcell response in healthy aviremic HCWs. This finding suggests that possible unapparent parenteral routes may stimulate host defenses with no evidence of hepatitis.

The observed pattern of a vigorous CTL response and relatively weaker humoral response predicting disease resolution suggests that $\mathrm{HCV}$ persistence also relates to the pattern of cytokine release [14]. Persistence may relate to a relative insensitivity of $\mathrm{HCV}$ to antiviral cytokines such as TNF $\alpha$ and IFN $\gamma$ [10,18],since viral clearance was associated with a greater magnitude and broader specificity of IFNY and IL2 responses [37]. Finally the frequent and low levels of HCV viremia may have been controlled by innate immune responses without a strong adaptive immunity [8].

Cross-reactivity to other commonly encountered antigens is an alternative explanation for the $\mathrm{T}$ cell responses found However, a range of viral proteins elicited responses, including the structural proteins core as well as the nonstructural proteins, with no single antigen standing out as immunodominant. These $\mathrm{T}$ cell responses suggest that our subjects were indeed exposed to HCV.

Cell-mediated immune (CMI) responses to hepatitis $\mathrm{C}$ virus $(\mathrm{HCV})$ antigens in adults without seroconversion or viraemia are biomarkers for prior transient infection [14]. It may be stipulated that these CMI-positive HCV seronegative subjects may have had a transient very mild infection, possibly associated with low-dose exposure to the virus, which was cleared. Conventional mechanisms for sustaining $\mathrm{T}$ cell memory are likely to be involved, including cytokine-driven homeostatic proliferation [38].

NS4 and NS5 protein antigens represent immunogenic, possibly protective, regions of the $\mathrm{HCV}$ genome in this group of positive PI HCW. The protective nature of NS5 peptide has been previously reported in uninfected siblings of HCV chronically infected children [14].

The HCV-specific cytokine responses observed in aviremic, seronegative $\mathrm{HCW}$ were qualitatively and quantitatively different from those observed in chronic HCV HCW. Our results show that T-helper 1 type cytokines are produced following stimulation with nonstructural antigens (NS4, and NS5) by positive PI
HCW (who had resolved HCV infection) similar to the results demonstrated by others $[39,40]$.

Abdulwahab et al. (2012) demonstrated a strong and broad $\mathrm{HCV}$-specific IFN- $\gamma$ response without detectable viremia or seroconversion in more than half $(55.8 \%)$ of Egyptian HCW, with both CD4+ and CD4- T cells producing IFN- $\gamma$ (the highest responses were to NS3 \& NS5a). They did not find a significant correlation between the strength and breadth of the HCV-specific CMI in these seronegative aviremic subjects and their demographic, clinical, or laboratory data [41]. The latest research on Egyptian HCW conducted at Ain Shams University Hospital, Cairo included HCWs reporting occupational blood exposure who had neither anti-HCV antibodies (anti-HCV) nor HCV RNA, and were exposed to a HCV RNA positive patient. They were enrolled in a 6-month prospective cohort with follow-up visits at weeks 2, 4, 8, 12 and 24. During follow-up, anti$\mathrm{HCV}, \mathrm{HCV}$ RNA and ALT were tested. Of $73 \mathrm{HCWs}$ exposed to HCV RNA from index patients, nine presented transient viremia, the majority of which occurred within the first two weeks after exposure. None of the workers presented seroconversion or elevation of ALT. The authors concluded that HCWs of a general University hospital in Cairo were exposed to a highly viremic patient population and they experienced frequent occupational blood exposures, particularly in early stages of training. These exposures resulted in transient viremic episodes without established infection [42].

The cytokine response against viral protein antigens shown in our study was elicited when PBMCs were cocultured with recombinant $\mathrm{HCV}$ antigens without the addition of any particular cytokines in vitro for differentiation into effector cells. Immunological memory in these HCW may have been established upon a prior exposure to the virus and a subsequent exposure to the antigen was capable of inducing a prompt HCV-specific effector function ex-vivo, possibly providing antiviral protection. The maintenance of these effector T cell responses may be sustained by repeated low-level exposure to $\mathrm{HCV}$ and stimulation of memory cells.

\section{Conclusion}

In conclusion, we present our observation that a substantial percentage of $\mathrm{HCV}$-seronegative aviremic $\mathrm{HCW}$ who are potentially exposed to the virus by virtue of their occupation develop a protective TH1 cytokine profile which may have protected them from persistent infection and probably protects against subsequent exposure. An increased understanding of the cytokine environment early in HCV infection is important for the development of novel therapeutics to facilitate viral clearance. 


\section{Competing interests}

The authors declare that they have no competing interests.

\section{Authors' contribution}

MR designed data collection tools, monitored data collection for the whole research, interpreted the data and drafted and revised the paper. She is guarantor. $\mathrm{AH}$ analyzed the data, and drafted the paper. KA carried out the laboratory analysis and analyzed it. AA supervised the laboratory tests and drafted the article and revised it. RA monitored data collection, and revised the draftpaper. DS monitored data collection and laboratory analysis and revised the draft paper. KR carried out the laboratory analysis. SE revised the paper critically. All authors read and approved the final manuscript.

\section{Acknowledgements}

This work was supported by the authors with no external sources of funding.

\section{Author details}

${ }^{1}$ Ain Shams Faculty of Medicine Clinical Pathology Department, Abbassia square, Cairo, Egypt. ${ }^{2}$ Cairo Faculty of Medicine Department of Microbiology and Immunology, Kasr El Ainy St, Cairo, Egypt.

Received: 21 July 2012 Accepted: 3 May 2013

Published: 11 May 2013

\section{References}

1. Alter MJ: Prevention of spread of hepatitis C. Hepatology 2002, 36:593-598.

2. Kubitschke A, Bahr MJ, Aslan N, Bader C, Tillmann HL, Sarrazin C, Greten T, Wiegand J, Manns MP, Wedemeyer H: Induction of hepatitis C virus (HCV)specific T cells by needle stick injury in the absence of HCV-viraemia. Eur J Clinl Invest 2007, 37(1):54-64.

3. Rafik M, Aly D, Omar KA, Mamdouh R, Zaghloul M, Hamed WA: Preliminary assessment of hepatitis C virus infection among Egyptian health-care workers: prevalence and association with risk factors, The Proceedings of the 7th Conference of the Federation of African limmunology Societies (FAIS). Sharm El Sheikh. Fayoum Egypt: Fayoum University; 2009:8-11.

4. Abdelwahab S, Rewisha E, Hashem M, Sobhy M, Galal I, Allam WR, Mikhail N, Galal G, El-Tabbakh M, El-Kamary SS, Waked I, Strickland GT: Risk factors for hepatitis $C$ virus infection among Egyptian healthcare workers in a national liver diseases referral center. Trans R Soc Trop Med Hyg 2012, 106(2):98-103.

5. Zeremski M, Shu MA, Brown Q, Wu Y, Des Jarlais DC, Busch MP, Talal AH, Edlin BR: Evidence of hepatitis $C$ virus-specific interferon gammapositive $T$ cells in health care workers in an infectious disease department. J Viral Hepa 2009, 16(1):10-20.

6. Abdelhady W: HCV Specific Cell Mediated Immune Response in Health Care Workers. Thesis, Ain Shams Faculty of Medicine Clinical Pathology Department: M.Sc; 2009.

7. Lyons $A B$, Parish $C R$ : Determination of lymphocyte division by flow cytometry. J Immunol Methods 1994, 171(1):131-137.

8. Meyer MF, Lehmann M, Cornberg M, Wiegand J, Manns MP, Klade C, Wedemeyer $\mathrm{H}$ : Clearance of low levels of HCV vireamia in the absence of a strong adaptive immune response. J Virol 2007, 11(4):58

9. Post JJ, Pan Y, Freeman AJ, Harvey CE, White PA, Palladinetti P, Haber PS, Marinos G, Levy MH, Kaldor JM, Dolan KA, French RA, Lloyd AR, Rawlinson W: Clearance of hepatitis $C$ vireamia associated with cellular immunity in the absence of seroconversion in the hepatitis C: incidence and transmission in prisons study cohort. J Infect Dis 2004, 189(10):1846-1855

10. Koziel MJ, Wong DK, Dudley D, Houghton M, Walker BD: Hepatitis C virusspecific cytolytic $T$ lymphocyte and $T$ helper cell responses in seronegative persons. J Infect Dis 1997, 176(4):859-866.

11. Bronowicki JP, Vetter D, Uhl G, Hudziak H, Uhrlacher A, Vetter JM, Doffoel M: Lymphocyte reactivity to hepatitis $\mathrm{C}$ virus (HCV) antigens shows evidence for exposure to HCV in HCV-seronegative spouses of HCVinfected patients. J Infect Dis 1997, 176(2):518-522.

12. Kamal SM, Amin A, Madwar M, Graham CS, He Q, Al Tawil A, Rasenack J Nakano T, Robertson B, Ismail A, Koziel MJ: Cellular immune responses in seronegative sexual contacts of acute hepatitis C patients. J Virol 2004, 78(22):12252-12258

13. Al-Sherbiny M, Osman A, Mohamed N, Shata MT, Abdel-Aziz F, Abdel-Hamid M, Abdelwahab SF, Mikhail N, Stoszek S, Ruggeri L, Folgori A, Nicosia A,
Prince AM, Strickland GT: Exposure to hepatitis c virus induces cellular immune responses without detectable viremia or seroconversion. AmJTrop Med Hyg 2005, 73(1):44-49.

14. Hashem M, El-Karaksy H, Shata MT, Sobhy M, Helmy H, El-Naghi S, Galal G, Ali Z, Esmat G, Abdelwahab SF, Strickland TG, El-Kamary SS: strong hepatitis $\mathrm{C}$ virus (HCV)-specific cell-mediated immune responses in the Absence of viremia or antibodies among uninfected siblings of HCV chronically infected children. J Infect Dis 2011, 203(6):854-861.

15. Schmidt J, Neumann-Haefelin C, Altay T, Gostick E, Price DA, Lohmann V, Blum HE, Thimme R: Immunodominance of HLA-A2-restricted hepatitis $\mathrm{C}$ virus-specific CD8+ T cell Responses is linked to naïve-precursor frequency. J Virol 2011, 85(10):5232-5236.

16. Lechner F, Wong DK, Dunbar PR, Chapman R, Chung RT, Dohrenwend P, Robbins G, Phillips R, Klenerman P, Walker BD: Analysis of successful immune responses in persons infected with hepatitis $C$ virus. J Exp Med 2000, 191(9):1499-1512.

17. Spangenberg HC, Viazov S, Kersting N, Neumann-Haefelin C, McKinney D, Roggendorl M: Intrahepatic CD8 (+) T-cell failure during chronic hepatitis C virus infection. Hepatology 2005, 42(4):828-837.

18. Chang KM, Thimme R, Melpolder JJ, Oldach D, Pemberton J, MoorheadLoudis J, McHutchison JG, Alter HJ, Chisari FV: Differential CD4 and CD8 Tcell responsiveness in hepatitis $\mathbf{C}$ virus infection. Hepatology 2001, 33(1):267-276.

19. Lauer GM, Barnes E, Lucas M, Timm J, Ouchi K, Kim AY, Day CL, Robbins GK, Casson DR, Reiser M, Dusheiko G, Allen TM, Chung RT, Walker BD, Klenerman P: High resolution analysis of cellular immune responses in resolved and persistent hepatitis C virus infection. Gastroenterol 2004, 127(3):924-936.

20. Harari A, Dutoit V, Cellerai C, Bart PA, Du Pasquier RA, Pantaleo G: Functional signatures of protective antiviral T-cell immunity in human virus infections. Immunol Rev 2006, 211:236-254.

21. Pantaleo G, Harari A: Functional signatures in antiviral T-cell immunity for monitoring virus-associated diseases. Nat Rev Immunol 2006, 6:417-423.

22. Zimmerli SC, Harari A, Cellerai C, Vallelian F, Bart PA, Pantaleo G: HIV-1-specific IFN-gamma/IL2-secreting CD8 T cells support CD4-independent proliferation of HIV-1-specific CD8 T cells. Proc Natl Acad Sci 2005, 102:7239-7244.

23. Chang-you W, Ragheb JA, McDyer JF, Li Z, John S, Yu X: IL2 receptor blockade inhibits late, but not early, IFNy and CD40 ligand expression in human T cells: disruption of both IL12-dependent and independent pathways of IFNy production. J Immunol 2002, 169:2736-2746.

24. Brady MT, MacDonald AJ, Rowan AG, Mills KH: Hepatitis C virus nonstructural protein 4 suppresses Th1 responses by stimulating IL10 production from monocytes. Eur J Immunol 2003, 33(12):3448-3457.

25. Semmo N, Klenerman P: CD4+ T cell responses in hepatitis $C$ virus infection. World J Gastroenterol 2007, 13(36):4831-4883.

26. Pawłowska M, Halota W, Smukalska E, Grabczewska E: Serum IL2 and sIL2R concentration in children with chronic hepatitis B. Pol Merkur Lekarski 2005, 18(103):33-35.

27. Klenerman $P$, Lucas $M$, Barnes $E$, Harcourt G: Immunity to hepatitis $C$ virus: stunned but not defeated. Microbes Infect 2002, 4(1):57-65.

28. Williams M, Bevan M: Effector and memory CTL differentiation. Annu Rev Immunol 2007, 25:171-192.

29. Gruener $\mathrm{NH}$, Lechner $\mathrm{F}$, Jung MC, Diepolder $\mathrm{H}$, Gerlach $\mathrm{T}$, Lauer $\mathrm{G}$, Walker $\mathrm{B}$, Sullivan J, Phillips R, Pape GR, Klenerman P: Sustained dysfunction of antiviral CD8 (+) T lymphocytes after infection with hepatitis $C$ virus. J Virol 2004, 75(12):5550-5558.

30. Lamonaca V, Missale G, Urbani S, Pilli M, Boni C, Mori C, Sette A, Massari M, Southwood S, Bertoni R, Valli A, Fiaccadori F, Ferrari C: Conserved Hepatitis C Virus Sequences Are Highly Immunogenic for CD41 T Cells: Implications for Vaccine Development. Hepatology 1999, 30(4):1088-1098.

31. Wedemeyer $H$, He XS, Nascimbeni M, Davis AR, Greenberg HB, Hoofnagle $J$, Liang TJ, Alter $H$, Rehermann B: Impaired effector function of hepatitis $C$ virus-specific CD8+ T cells in chronic hepatitis $C$ virus infection. $\mathrm{J}$ Immunol 2002, 169(96):3447-3458.

32. Freeman AJ, George M, Rosemary AF, Lloyd AR: Immunopathogenesis of hepatitis C virus infection. Immunol Cell Biol 2001, 79:515-536.

33. Ruys TA, Nanlohy NM, van den Berg CH, Hassink E, Beld M, van de Laar T, Bruisten S, Wit F, Krol A, Prins M, Lange J. van Baarle D: HCV-specific T-cell responses in injecting drug users: evidence for previous exposure to $\mathrm{HCV}$ and a role for CD4+ T cells focusing on nonstructural proteins in viral clearance. J Viral Hepa 2008, 15:409-420. 
34. Yewdell JW: Confronting complexity: real-world immunodominance in antiviral CD8+ T cell responses. Immunity 2006, 25(4):533-543.

35. Schulze Z, Wiesch J, Lauer GM, Day CL, Kim AY, Ouchi K, Duncan J, Wurcel AG, Timm J, Jones AM, Mothe B, Allen TM, McGovern B, Lewis-Ximenez L, Sidney J, Sette A, Chung RT, Walker BD: Broad repertoire of the CD4 + Th cell response in spontaneously controlled hepatitis $C$ virus infection includes dominant and highly promiscuous epitopes. J Immunol 2005, 1759(6):3603-3613.

36. Perrella A, Grattacaso S, d'Antonio A, Atripaldi L, Sbreglia C, Gnarini M, Conti $P$, Vecchiet J, Perrella O: Evidence of hepatitis $C$ virus-specific interferon gamma-positive $T$ cells in health care workers in an infectious disease department. Am J Infect Control 2009, 37(5):426-429.

37. Flynn JK, Dore GJ, Hellard M, Yeung B, Rawlinson WD, White PA, Kaldor JM, Lloyd AR, French RA: Early IL-10 predominant responses are associated with progression to chronic hepatitis $\mathrm{C}$ virus infection in injecting drug users. J Viral Hepa 2011, 18(8):549-561.

38. Welsh $\mathrm{R}$, Selin $\mathrm{L}$ : No one is naive: the significance of heterologous $T$ cell immunity. Nat Rev Immunol 2002, 2(6):417-426.

39. Rosen HR, Miner C, Sasaki AW, Lewinsohn DM, Conrad AJ, Bakke A, HG, Hinrichs DJ: Frequencies of HCV-specific effector CD4+ T cells by flow cytometry: correlation with clinical disease stages. Hepatology 2002, 35:190-198.

40. Diepolder HM, Zachoval R, Hoffmann RM, Wierenga EA, Santantonio T, Jung MC, Eichenlaub D, Pape GR: Possible mechanism involving T-lymphocyte response to non-structural protein 3 in viral clearance in acute hepatitis C virus infection. Lancet 1995, 346:1006-1007.

41. Abdelwahab S, Zakaria Z, Sobhy M, Rewisha E, Mahmoud MA, Amer MA, Del Sorbo M, Capone S, Nicosia A, Folgori A, Hashem M, El-Kamaryh SS: Hepatitis C virus-multispecific T-cell responses without viremia or seroconversion among egyptian health care workers at high risk of infection. Clin Vaccine Immunol 2012, 19(5):780-786.

42. Munier A, Marzouk D, Abravane F, El-Daly M, Taylor S, Mamdouh R, Salah Eldin W, Ezz El-Arab H, Gaber Sos D, Momen M, Okasha O, Le Fouler L, ElHosini M, Izopet J, Rafik M, Albert M, Abdel-Hamid M, Kamal M, DelarocqueAstagneau E, Fontanet A: Frequent transient hepatitis C viremia without seroconversion among healthcare workers in Cairo. Egypt. PLOS ONE 8(2): e57835. doi:10.1371/journal.pone.0057835.

doi:10.1186/1743-422X-10-144

Cite this article as: Rafik et al: $\mathrm{TH} 1$ cytokine response to HCV peptides in Egyptian health care workers: a pilot study. Virology Journal 2013 10:144.

\section{Submit your next manuscript to BioMed Central and take full advantage of:}

- Convenient online submission

- Thorough peer review

- No space constraints or color figure charges

- Immediate publication on acceptance

- Inclusion in PubMed, CAS, Scopus and Google Scholar

- Research which is freely available for redistribution 